\title{
Book Reviews: Clinical Experiences, Indoctrination and Education in Alcoholism
}

Marguerite M. Blythe, M.D.

University of Cincinnati, Cincinnati Ohio

Follow this and additional works at: https://jdc.jefferson.edu/jeffjpsychiatry

Part of the Psychiatry Commons

Let us know how access to this document benefits you

\section{Recommended Citation}

Blythe, M.D., Marguerite M. (1989) "Book Reviews: Clinical Experiences, Indoctrination and Education in Alcoholism," Jefferson Journal of Psychiatry. Vol. 7 : Iss. 2 , Article 15.

DOI: https://doi.org/10.29046/JJP.007.2.014

Available at: https://jdc.jefferson.edu/jeffjpsychiatry/vol7/iss2/15

This Article is brought to you for free and open access by the Jefferson Digital Commons. The Jefferson Digital Commons is a service of Thomas Jefferson University's Center for Teaching and Learning (CTL). The Commons is a showcase for Jefferson books and journals, peer-reviewed scholarly publications, unique historical collections from the University archives, and teaching tools. The Jefferson Digital Commons allows researchers and interested readers anywhere in the world to learn about and keep up to date with Jefferson scholarship. This article has been accepted for inclusion in Jefferson Journal of Psychiatry by an authorized administrator of the Jefferson Digital Commons. For more information, please contact: JeffersonDigitalCommons@jefferson.edu. 


\title{
Book Reviews
}

\section{Clinical Experiences, Indoctrination and Education in Alcoholism}

\author{
HEAVY DRINKING: THE MYTH OF ALCOHOLISM AS A DISEASE \\ Herbert Fingarette \\ Berkeley, University of California Press \\ 1988, 166 pages
}

Marguerite M. Blythe, M.D.

The identities of all patients described in this article have been disguised to protect their privacy.

Sooner or later every physician encounters an alcoholic patient who deals with heavy drinking in ways that our treatment models explain poorly, if at all.

Mrs. Smith was a 73 year old black woman who had drank heavily for many years, usually to intoxication. Her husband was alcoholic and they often got into serious fights, sometimes with one or the other hospitalized. Mrs. Smith thought she too might have been an alcoholic, though no one ever called her this. Her husband left her and she drank even more heavily. Her daughters complained that she was killing herself with drink and begged her to quit. They urged her to go to A.A. Once twenty-five or thirty years ago Mrs. Smith had gone to an A.A. meeting and had decided she wanted no part of that. "Was just like church," she explained, "only worse ... no music." Mrs. Smith, however, decided her daughters were right: so she stopped drinking. That was 15 years ago. She never has alcohol and wishes that some of her friends would quit too. It wasn't easy to quit, she admits, but then she'll add, her drinking wasn't easy either.

Mr. Cocina had a six pack of beer most evenings but on weekends went through a 12-pack and occasionally a 24-pack daily. He worked night shift in a factory. He never missed work and never drank at work. Sometimes when he got off work in the mornings he was shakey. He felt he needed a drink at these times so he'd have one and then go to bed. His family had many financial problems and his wife left him for a period, after attempting suicide when his two daughters were 3 and 5 . The girls told him he smelled bad when he drank and complained when he forgot the things they needed for pre-school. Otherwise he cared well for the children even though he'd been brought up in a culture where men didn't do that. Mr. Cocina had been told that he was an alcoholic and had had 
pancreatitis twice. He didn't believe he was really an alcoholic because he never got drunk. He could go for days without a drink when he put his mind to it, even if he felt shakey and a little sick for the first few days. However, his children's comments bothered him, especially since he wasn't sure what would happen between him and his wife and whether he might be the only parent they'd have. He decided to cut back on the beer. At first he decided no more than a six pack a day including weekends. Then he cut back to three beers a day while still allowing a six-pack weekends. Eight years later he still drinks two or three beers a day, six packs on weekends. He had another bout of pancreatitis four years ago but mostly he is in good health. His wife is back with the family and she confirms the quantity he drinks, though she admits she wonders about whether it is good for him because of the pancreatitis and because "he used to be an alcoholic."

The first patient simply stopped drinking, but she did stop drinking entirely, even if she stopped without outside support. The second patient cut back significantly for eight years. He didn't stop and he had at least one serious alcohol related illness. He never resumed the heavy drinking that had characterized the months before his wife left the family. He was not, however, abstinent, and by most alcohol treatment criteria, he would be called a problem drinker. A.A. would predict that the reprieve is temporary. If he's really an alcoholic, the control won't last; he will continue to get worse until he hits bottom.

Alcoholism is not one clear cut entity, or a simple straight-forward problem that has one manifestation, even as these two case histories show. While $\mathrm{Mr}$. Cocina has controlled his drinking for eight years, others cannot control their drinking for a day, but some manage to do so for a lifetime. How can such differences be explained?

Herbert Fingarette's book, Heavy Drinking: The Myth of Alcoholism as a Disease, was published in 1988 to inform the "American public that almost everything it believes to be the scientific truth about alcoholism is false" (1). This introduction may make the reviewer wonder whether Professor Fingarette is a pop writer with a belief system to propogate, or a scholar who is seriously examining drinking. The number of footnotes and their sources quickly convince the reader that the author has a vast and working knowledge of the field of alcoholism. Furthermore the book, even if aimed at the non-medical public, might be helpful to physicians who are trying to account for differences among alcoholics, or explain why some heavy drinkers can stop or cut back significantly on their drinking without help while others wind up on skid-row with the best of treatment.

The book is divided into seven chapters, each of which ends with a list of notes. The author claims citations have been deliberately kept brief so as to appeal to the general reader and not the scientist (2). The reader can, indeed, skip the notes and still easily follow the author's arguments. Professor Fingarette's references, however, fill more than ten percent of the 145 pages of text. While he neither goes to extremes in documenting his statements nor lists multiple sources when one would do, most academics would have few problems 
with Professor Fingarette's citations. It is not the brevity of the author's footnotes, but his simple, straight-forward style of writing that is likely to appeal to the general reader. Jargon and medical terminology have been kept at a minimum or translated into standard English. Sentence structure is well written and terse. The book is easily read in a few hours.

The author describes the classic disease concept of alcoholism quite clearly, frequently drawing on sources used by A.A., such as Mann's 1950 Primer on Alcoholism and Jellinek's articles. To summarize, most people can tolerate alcohol without a problem but for certain at-risk drinkers (alcoholics), alcohol triggers an uncontrollable need for more alcohol, a need which is physiologically based and, hence, a disease. Progressive deterioration occurs in predictable stages and with regular symptom patterns as the disease worsens. Unless an alcoholic is totally abstinent, the disease is fatal. Chronic heavy drinkers do not stop their consumption of alcohol because they cannot; they have lost control over the ability to stop. Despite medical, emotional, social and financial problems engendered by drinking, once the alcoholic starts drinking, he or she has started a chain reaction. One drink leads to another despite the alcoholic's intentions or resolutions to stop after one or two drinks. Loss of control, however, may occur in different ways. Jellinek thought there were at least five different types of alcoholics. Delta alcoholics, for example, have no control over whether or not to drink and they drink all day everyday, usually without becoming grossly intoxicated. (The French wine drinker is the classic example of this type of alcoholic, as, indeed, may Mr. Cocina have been in his heavy drinking days.) Gamma alcoholics can choose to take the first drink, but once that drink is taken it triggers a loss of control and the drinker continues to drink until external circumstances intervene. There may, for example, be no more liquor available or the alcoholic may be too sick or drunk to continue.

Fingarette draws on a wide array of studies in questioning the usefulness of the classic disease model of alcoholism. While the author looks at sociological, scientific, psychological, and educational arguments for and against the disease concept, the arguments against the disease model clearly predominate. He cites literally dozens of studies that undermine the disease model of alcoholism but only a few can be noted in this review.

Professor Fingarette questions Jellinek's own scientific methods, since Jellinek's writings have been the basis of much of the disease model doctrine. (Jellinek's articles were based on questionnaires completed by 98 male members of A.A.; he had excluded 60 questionnaires that contained pooled data and all women's questionnaires.) The author quotes a number of researchers whose conclusions conflict with the universality of the classic disease model of alcoholism and loss of control. As early as the late 1960's, NCA surveys of heavy drinking drew a picture of the epidemiology and progression of alcoholism different from Jellinek's disease stages. George Vaillant's work shows that an alcoholic's control (or loss of control) is not simply a function of physiology but often is influenced by psychological and sociological factors. Even genetic 
studies, which are most often quoted to support the disease concept, can be interpreted in many ways. Donald Goodwin's genetic studies of adopted children of alcoholics show that $18 \%$ of the biological sons of alcoholics become alcoholic as compared to $5 \%$ of the sons of non-alcoholics; however, rather than simply show that a genetic or biochemical basis for alcoholism exists (which is how this data is usually interpreted), Goodwin's work also shows that MOST alcoholics do not produce alcoholic sons; even if sons of alcoholics are 3.5 times more likely to become alcoholics than the sons of non-alcoholics, the majority of the sons of alcoholics $(82 \%)$ do not become alcoholic. Which statistic one quotes depends on what one wishes to emphasize.

The professional literature quoted in this book is well known to scientists and physicians who deal with alcoholism. The author acknowledges this early in the book. He states that he is trying to make scientific knowledge available to a public whose conception of alcoholism is based largely on myth. However, even if a reader already believes, as Fingarette suggests; that there are probably many forms of alcoholism, that we really don't have a clear idea of what biochemically causes most interactions between brain and behavior, and that "the concept of loss of the capacity for controlled drinking is, at best, a relative concept" (3), some readers will find the author's descriptions of A.A. provocative. Fingarette is likely to make few friends by pointing out bluntly that "the vast majority of heavy drinkers never try A.A., and most who join drop out" (4) even when he quotes research to support this statement. Everpresent good opinion exists about A.A., just as it does for apple pie and motherhood. Proclaiming the deficits of A.A., even if true, is guaranteed to stir strong feelings among the committed. He reminds the reader; that no more than $5 \%$ of all alcoholics are members of A.A., that in one study only $22 \%$ of regular members were sober at 30 months, and that many research studies show A.A. is not the only way (or even a good way) to help the majority of heavy drinkers. Sympathizers and believers have viewed such statements as attacks on A.A.

I asked six people, all of whom work in alcohol treatment, what they thought of this book. One declined to answer because she had not read the book. One had read only a review and had mixed feelings about recommending the book, but admitted that this might be because of the review he had read. The other four decided against reading the book entirely because they believed, either from its title or from comments they had heard about the book, that it was a diatribe against A.A. and an uneducated attack on the disease concept of alcoholism. This very small group was NOT statistically significant in size OR randomly sampled. (They had to know me to get asked about the book and I asked about it casually before I had read the book myself.) These people worked in three different treatment facilities and included two women, one physician, two psychologists, one social worker and two counsellors.

Even given the questionable usefulness of the sample I polled, the author is unlikely to be idolized by hospital-based alcohol treatment centers who operate on an A.A. and disease based model of alcoholism. Fingarette describes the 
results of many treatment studies that had depressing patient outcomes. He includes Vaillant's elaborate eight year experiment by candidly quoting, "there is compelling evidence that the results of our treatment were no better than the natural history of the disease"' (5).

The purpose of this book is not, however, to attack A.A. or all that is near and dear to the heart of alcoholism workers. It's purpose is to point out facts, even unpleasant ones, ones we'd rather ignore. Ones that do not agree with what we'd like to believe is true. Over and over the book reminds the reader to make evaluations based on observations, not on slogans, feelings, myths, or preconceived ideas.

The second half of the book addresses why we should examine these facts. Rejecting the classical ideas of loss of self control and the disease model can be useful in looking at heavy drinking. Since, in science our models define what we study and our underlying scientific beliefs determine what we will accept, reject or even examine as evidence; dropping the classic model of alcoholism as a disease leads to Fingarette's most interesting thoughts on drinking. The ideas most likely to engender serious thought in scientific readers are found in the second half of the book. Here the author examines heavy drinking as a way of life. He looks at non-traditional ways of treating the heavy drinkers who are not helped by our present system; he looks at European models for treatment which are less influenced by A.A., including flexible measures of success. The social implications of heavy drinking are considered from the points of view of influencing behavior, of liability and of protection, both for drinkers and for those around them.

For the physician, the section on flexible measures of success is particularly valuable. Doctors routinely deal with less than perfect outcomes in therapy. Hypertension, for example, is controlled (sometimes better and sometimes worse) but it is not cured. Nor is schizophrenia. The author argues that it is unrealistic to view a drinker's efforts as an all-or-none affair, just as I would argue that treating hypertension or schizophrenia meets with varying degrees of success. Instead of judging success solely by the criterion of abstinence from drinking, physicians and researchers might look at reductions in the number of drinking days a month, or the amount drunk at one time, or a marked reduction in the number of days off the job.

Measuring such outcomes and acknowledging them as achievements does not imply that they should be set as goals. To return to the hypertension example, calling a diastolic blood pressure of 100 better than one of 110 does not imply that treatment should stop at 100 . The goal of hypertension treatment should be a diastolic blood pressure within the commonly accepted normal ranges. But grouping all non-abstainers together in outcome measures of alcohol treatment is like grouping together everyone who does not have a diastolic blood pressure of 80 in measures of hypertension treatment. This can be counterproductive. It can also be misleading as it minimizes improvements that were accomplished in the groups that did not reach sobriety or perfect diastolic 
readings. For example, a four year follow-up study of 780 alcoholics in eight treatment centers showed 30\% achieved long-term abstinence. (This is about average.) However, of the other $70 \%$, the "failures," the rate of drinking was significantly decreased (down about $70 \%$ ), physical dependence symptoms were down by about $60 \%$, and problem drinking down from over $90 \%$ to $54 \%$ (6).

$\mathrm{Mr}$. Cocina, the patient described on the first page of this review, had some successes in dealing with his alcoholism. His outcome was mixed, however. He still has some alcohol-related physical problems. He still drinks a case of beer a week. To call him a failure because he isn't completely abstinent, or to ignore what he has accomplished does him a disservice. It probably also makes the person who considers Mr. Cocina a treatment failure unbelievable to the patient. How many patients are lost to treatment because the physician doesn't believe their efforts are worth enough, or that they are good enough patients? The hypertensive patient whose blood pressure is poorly controlled may not return to the physician who accused him of not taking his multiple blood pressure medications, whether he did take them or not. Much has been written on the psychiatric patient who is blamed for not getting well according to the doctor's standards $(7,8,9)$.

Education in alcoholism is becoming an increasing concern to residency training committees (10). The quantity and quality of teaching in this area varies from program to program. Residents do need to know basic concepts in alcoholism. Fingarette's little book gives an excellent overview of traditional thinking on the disease model of alcoholism, as well as an introduction to well known studies on alcoholism and researchers in this area. While his book is not a review, he manages to cover many topics that would be included in a general overview of this area. Psychiatric residents are commonly given articles to read during their educational process. Some accompany lectures. Some mention a topic in passing that might have come up in supervision. The result is a patchwork of written ideas which not only do not logically fit together, they often contradict one another. Fingarette's book would be a good starting place for residents to begin to learn about alcoholism. It would also be a good place to begin a review of the subject or to brush up on forgotten concepts. While it is not a text book, it includes a well written, logical description of the disease model. This is given in an historic context; then recent scientific data is used to show how the 1930's ideas that predominate lay thinking must be examined in light of recent research. The author poses questions about what different models might mean to the future of research and treatment in alcoholism. He leaves the reader to answer some difficult questions.

Since few residents read everything that is given them, and even fewer can indulge in mastering many texts in sub-specialty areas of psychiatry, if I were going to require residents to read one book on alcoholism, it would be this one. It is well written, short, and covers the literature in a fashion that should be satisfactory to the beginning reader. It forces the more advanced reader to think. How many writings in any field can claim the same qualities? 


\section{REFERENCES}

1. Fingarette H: Heavy Drinking: The Myth of Alcoholism as a Disease. Berkeley, University of California Press, p 1, 1988

2. Fingarette, p. 2

3. Vaillant G: The Natural History of Alcoholism. Cambridge Mass, Harvard University Press, 1983 as quoted in Fingarette H: Heavy Drinking: The Myth of Alcoholism as a Disease. Berkeley, University of California Press, p 43, 1988

4. Fingarette p. 89

5. Vaillant G: The Natural History of Alcoholism. Cambridge Mass, Harvard University Press, 1983 as quoted in Fingarette H: Heavy Drinking: The Myth of Alcoholism as a Disease. Berkeley, University of California Press, p 70, 1988

6. Polich J, Armor DJ, Braiker HB: The Course of Alcoholism: Four Years After Treatment. Santa Monica, The Rand Corp, 1980 as quoted in Fingarette H: Heavy Drinking: The Myth of Alcoholism as a Disease. Berkeley, University of California Press, p 122, 1988

7. Slakter E, ed: Countertransference: A Comprehensive View of Those Reactions of the Therapist to the Patient That May Help or Hinder Treatment. Northvale NJ, Jason Aronson, 1987

8. Gorkin ML: The uses of Countertransference. Northvale NJ, Jason Aronson, 1987

9. Robertiello RC, Schoenewolf G: 101 Common Therapeutic Blunders: Countertransference and Counteresistance in Psychotherapy. Northvale NJ, Jason Aronson, 1987

10. Galanter M, Kaufman E, et al: The current status of psychiatric education in alcoholism and drug abuse. Am J Psychiatry 146:35-39, 1989 